\title{
UMBATRA
}

Indonesian Journal of Anthropology

Volume 3 (1) Juli 2018 || eISSN 2528-1569 | pISSN 2528-2115 || http://jurnal.unpad.ac.id/umbara

DOI : $10.24198 /$ umbara.v3i1.25571

\section{Pemahaman dan Praktik Pencegahan Tekanan Darah Tinggi di Desa Cilayung (Tinjauan Antropologis)}

\author{
Anisa Nur Ropika \\ Sahabat Pulau Indonesia \\ ropika@sahabatpulau.org
}

\begin{abstract}
This research discusses the understanding and practice of high blood pressure prevention and treatment in Desa Cilayung using medical anthropology perspective. This research applied qualitative method, in particular, ethnography. The data were collected through participant observation and in-depth interview. The results of this research indicate that people in Desa Cilayung understand high blood pressure as a disease caused by excessive mental pressure, excessive physical activity, and excessive salt consumption. Practices for prevention and treatment include reducing causal factors and taking medicines from biomedical practitioners and ethnomedicine from traditional healers or medicinal plants they obtain from their homegarden. This understanding and practices have been influenced by people's local belief on disease etiology and its treatment.
\end{abstract}

Keywords: High blood pressure, health, practices of prevention, anthropological study

\begin{abstract}
Abstrak
Penelitian ini membahas pemahaman dan praktik pencegahan dan penanggulangan penyakit tekanan darah tinggi oleh masyarakat di Desa Cilayung ditinjau dari sudut pandang Antropologi Kesehatan. Penelitian ini menggunakan metode kualitatif model etnografi. Teknik pengumpulan data dilakukan dengan cara pengamatan terlibat dan wawancara mendalam. Hasil penelitian ini menunjukkan bahwa masyarakat memahami penyakit tekanan darah tinggi sebagai penyakit yang disebabkan terlalu banyak pikiran, terlalu banyak aktivitas, terlalu banyak konsumsi garam, dan faktor keturunan. Praktik yang dilakukan masyarakat untuk mencegah dan menanggulangi tekanan darah antara lain mengurangi penyebab dan mengonsumsi obat-obatan dari produk biomedis, etnomedisin, dan juga herbal yang diperoleh dari pekarangan. Pemahaman dan praktik masyarakat pada pencegahan dan penanggulangan dipengaruhi oleh pemahaman dan keyakinan masyarakat pada konsep lokal mengenai penyakit dan cara-cara penanggulangannya.
\end{abstract}

Kata kunci: Tekanan darah tinggi, kesehatan, praktik pencegahan, kajian antropologi 


\section{Pendahuluan}

Penyakit tekanan darah tinggi merupakan penyakit tidak menular yang saat ini banyak diderita oleh penduduk Indonesia (Palemer dan Williams, 2007). Data Kementerian Kesehatan pada 2016 menyatakan bahwa sebanyak 25,8\% penduduk Indonesia menderita darah tinggi. Penyakit ini disebut 'pembunuh senyap' karena muncul tanpa keluhan sehingga banyak masyarakat yang tidak mengetahui bahwa mereka mengidap tekanan darah tinggi (Galton, 1973). Beberapa penelitian menunjukkan bahwa penyakit tekanan darah tinggi disebabkan oleh faktor genetik dan non-genetik. Faktor non-genetik yang seringkali memicu darah tinggi adalah gaya hidup. Pola diet tinggi natrium (garam) dan lemak, kurang beraktivitas fisik, dan merokok adalah gaya hidup yang paling umum memicu tekanan darrah tinggi (William, 2008). Faktor non genetik pada dasarnya dapat ditanggulangi dengan mengadopsi pola hidup sehat.

Pengidap darah tinggi umumnya mendatangi tempat layanan kesehatan ketika kondisinya sudah parah. Penanggulangan darah tinggi di Indonesia dilakukan oleh pemerintah dengan memberikan pengobatan gratis di Puskesmas dan memberikan pembinaan layanan Posbindu (Pos Pembinaan Terpadu) untuk pencegahan dan penanggulangan Penyakit Tidak Menular (Posbindu PTM) sebagai wadah deteksi dini.

Saat ini, tingkat kepatuhan berobat pasien darah tinggi di Indonesia sangat rendah meski mereka memiliki pengetahuan yang memadai mengenai penyakit tersebut. Selain itu, kemauan untuk melakukan praktik pencegahan penyakit pun sangat rendah (Muhammadun, 2010). Hal ini kemungkinan berkaitan dengan budaya kesehatan masyarakat, terutama mengenai konsep lokal penyakit, pencegahan, dan penanggulangannya. Pemahaman masyarakat mengenai penyakit dan praktik yang mereka lakukan untuk mencegah dan menanggulangi suatu penyakit sangat dipengaruhi dan dibentuk oleh kebudayaan yang berlaku di suatu masyarakat (Notoatmodjo, 2010).

Beberapa studi etnografi pernah dilakukan un- tuk menelusuri dan menggambarkan pemahaman dan tanggapan masyarakat pada penyakit tekanan darah tinggi, pencegahan dan penanggulangannya. Widyasari (2014) melakukan studi etnografi mengenai pencegahan dan penanggulangan penyakit darah tinggi di ma syarakat Jeneponto, Provinsi Sulawesi Selatan. Masyarakat Jeneponto menyebut tekanan darah tinggi dengan istilah 'tinggi dara'; dan menganggap penyakit tersebut sebagai penyakit orang kaya. Masyarakat meyakini penyakit tersebut disebabkan oleh terlalu banyak konsumsi protein seperti daging, ayam, atau ikan. Meskipun tekanan darah tinggi dianggap sebagai sebuah penyakit oleh masyarakat Jeneponto, tetapi penyakit tekanan darah tinggi tidak dikategorikan sebagai penyakit yang gawat sebab pengidap tekanan darah tinggi masih dapat melakukan aktivitas sehari-hari. Di dalam konsep lokal masyarakat Jeneponto penyakit yang tidak membuat seseorang terganggu dalam melakukan aktivitas sehari-hari, tidak dianggap sebagai penyakit gawat. Badan yang pegal-pegal serta kaku di sekitar bagian leher, pusing yang berkepanjangan, pandangan gelap, dan penglihatan berputar-putar dipahami masyarakat Jeneponto sebagai gejala darah tinggi. Apabila mereka mengalami gejala tersebut, biasanya mereka mengonsumsi obat yang dibeli di warung dan beristirahat. Namun, apabila gejala tidak mereda selama berhari-hari dan pengobatan yang mereka lakukan tidak membuahkan hasil, mereka mendatangi pelayanan kesehatan, yaitu Puskesmas, Poskesdes, bidan desa, atau Polindes.

Studi etnografi mengenai darah tinggi juga dilakukan oleh Mulyantoro et al., (2016) di Piabung, Kabupaten Kepulauan Anambas, Provinsi Riau. Masyarakat Piabung mengenal penyakit tekanan darah tinggi dengan istilah lokal 'tensi'. Masyarakat Piabung mengetahui bahwa tekanan darah tinggi adalah suatu penyakit serius dan mereka juga memahami gejala dan penyebabnya. Di dalam praktik sehari-hari, masyarakat memeriksakan diri ke Puskesmas ketika mereka mulai merasakan 
gejala yang mereka kenali sebagai gejala tekanan darah tinggi. Mereka juga melakukan berpantang makanan sebagai upaya meredakan tekanan darah tinggi. Kejadian penyakit darah tinggi di Piabung berkaitan erat dengan pola makan masyarakat. Ikan adalah jenis makanan yang paling banyak tersedia dan paling banyak dikonsumsi di Piabung, sementara sayuran dan buah kurang dikonsumsi karena tidak banyak ditanam. Mereka mengenal istilah bahwa 'belum makan jika belum makan ikan'. Ikan diolah dengan menggunakan santan yang banyak karena tanaman kelapa melimpah. Garam ditambahkan untuk menciptakan rasa gurih atau yang mereka sebut dengan rasa 'lemak'. Rasa asin dan gurih pada masakan dibuat dengan menambahkan garam dan bumbu penyedap. Konsumsi makanan tinggi garam dan lemak serta kurangnya konsumsi sayuran dan buah kemungkinan besar menjadi penyebab tekanan darah tinggi di kalangan masyarakat Piabung (Mulyantoro et al., 2016)

Penelitian ini menggunakan perspektif Antropologi Kesehatan untuk menelusuri dan menggambarkan pemahaman dan praktik masyarakat dalam upaya pencegahan dan penanggulangan penyakit tekanan darah tinggi di Desa Cilayung, Kecamatan Jatinangor, Kabupaten Sumedang, Provinsi Jawa Barat yang berlatar belakang budaya Sunda. Penelitian ini juga akan melihat kaitan antara budaya kesehatan dalam masyarakat Sunda dengan praktik yang dilakukan masyarakat.

Di dalam keluarga terjadi proses sosialisasi mengenai aneka hal, salah satunya sosialisasi mengenai peran gender. Gender adalah perbedaan karakteristik, peran, fungsi, hak, tanggung jawab, dan perilaku antara laki-laki dan perempuan yang dibentuk oleh nilai sosial, budaya, dan adat istiadat masyarakat.

\section{Kajian Pustaka}

\section{Etiologi darah tinggi}

Tekanan darah tinggi atau hipertensi adalah kondisi medis di mana seseorang mengalami peningkatan tekanan darah secara kronis (dalam jangka waktu lama); atau jika tekanan darahnya melebihi 120/80 mmHg (Hartati dan Fani, 2017). Secara fisiologis, tekanan darah tinggi terjadi saat dinding arteri mengalami penebalan sehingga menyebabkan hilangnya elastisitas. Elastisitas dinding arteri yang rendah menyebabkan jantung kesulitan memompa darah dan menyebabkan tekanan darah menjadi naik. Secara umum kejadian tekanan darah tinggi disebabkan oleh faktor yang tidak dapat diubah atau dikontrol (genetik) dan faktor yang dapat diubah atau dikendalikan (non-genetik). Faktor yang tidak dapat diubah adalah riwayat keluarga dengan tekanan darah tinggi, umur, ras, dan etnik. Sedangkan faktor yang dapat diubah atau dikendalikan adalah konsumsi garam, konsumsi alkohol dan rokok, olahraga, serta pola hidup yang dapat menyebabkan obesitas (William, 2008; Saraswati, 2009).

Pencegahan tekanan darah tinggi dapat dilakukan dengan berbagai cara, di antaranya: 1) mengurangi asupan garam dalam makanan, 2) mengonsumsi makanan mengandung kalium, magnesium dan kalsium, 3) mengurangi makanan dan minuman beralkohol, 4) melakukan olahraga secara teratur, 5) konsumsi sayur dan buah yang berserat tinggi (sayuran hijau, pisang, tomat, wortel, melon, dan jeruk), 6) menjalankan terapi anti stres agar mengurangi stres dan mampu mengendalikan emosi, 7) berhenti merokok (Nurfita, 2012). Namun, diantara upaya pencegahan tekanan darah tinggi tersebut, mengatur kebiasaan makan termasuk upaya yang paling sulit dilakukan.

Kebiasaan makan adalah tingkah laku manusia atau kelompok manusia dalam memenuhi kebutuhannya akan makan yang meliputi sikap, kepercayaan, dan pemilihan makanan (Khumaidi, 1989). Kebiasaan makan juga didefinisikan sebagai bentuk reaksi individu terhadap dampak fisiologis, psikologi sosial, dan budaya yang muncul dari pilihan pangan (Suhardjo, 1989). Kebiasaan makan individu dipengaruhi oleh tiga faktor penting, yaitu: 1) ketersediaan pangan, 2) pola sosial budaya, dan 3) faktor-faktor pribadi (Harper, Deaton, dan Driskel, 1985). Selain itu, kebiasaan makan juga dipengaruhi kepercayaan, tantangan, atau sikap individu terhadap makanan 
(Wahyuni, 1988). Kebiasaan makan individu biasanya terbentuk sejak kecil. Beberapa literatur menyebutkan faktor-faktor yang membentuk kebiasaan makan individu sejak kecil, yaitu: 1) latar belakang etnis, 2) tingkat sosial ekonomi, 3) geografi, 4) iklim, 5) agama dan kepercayaan, 6) tingkat kemajuan teknologi, 7) lingkungan budaya, 8) situasi demografi, 9) mobilitas, 10) umur, 11) jenis kelamin (Den Hartog, Van Staveren, dan Brower, 1995; Prayugi, Mursaha, dan Lewa, 2017; Wardiatmo, 1989).

Di beberapa masyarakat, penyakit tekanan darah tinggi memiliki sebutan lokal yang berbeda-beda. Masyarakat di Jeneponto, Provinsi Sulawesi Selatan, menyebut tekanan darah tinggi dengan istilah lokal 'tinggi dara'. Masyarakat Makassar menyebut tekanan darah tinggi dengan istilah nai 'cera'. Nai 'berarti naik dan cera 'berarti darah dalam Bahasa Makassar (Widyasari, 2014) . Masyarakat Piabung, Provinsi Riau menyebut tekanan darah tinggi dengan istilah lokal 'tensi' (Mulyantoro et al., 2016); dan masyarakat Jawa Timur mengenal penyakit tekanan darah tinggi dengan istilah bludreg (Hanif dan Asri, 2016).

Masyarakat melakukan aneka bentuk tanggapan pada kejadian penyakit tekanan darah tinggi dan cara pencegahannya. Masyarakat Jeneponto di Sulawesi Selatan menggunakan obat-obatan herbal untuk mengobati tekanan darah tinggi selain mengandalkan obat yang diperoleh dari layanan kesehatan. Beberapa herbal yang sering mereka gunakan antara lain: daun sendok, daun alpukat, labu siam, dan daun seledri. Berkaitan dengan pencegahan, masyarakat menghindari konsumsi kacang-kacangan beserta daunnya, daun kelor, terong, kol, daging kuda, ikan kering, dan ebi (Widyasari, 2014).

\section{Definisi Sehat, Sakit, dan Penyakit}

Sehat dan sakit adalah sebuah konsep yang didefinisikan dan dipahami dengan cara berbeda di setiap masyarakat. Cara pendefinisian dan pemahaman sangat dipengaruhi oleh kepercayaan dan tradisi. Konsep sehat didefinisikan sebagai situasi kenyamanan dalam beraktivitas yang dirasakan oleh individu.
Kenyamanan ini muncul karena unsur-unsur dalam tubuh atau cairan dalam tubuh seimbang. Konsep sakit didefinisikan sebagai situasi ketidaknyamanan dalam beraktivitas yang dirasakan oleh individu. Dengan demikian 'sakit' dan 'sehat' adalah situasi yang dialami oleh individu secara subjektif (Foster dan Anderson, 1986).

Konsep penyakit didefinisikan dengan cara yang beragam di masyarakat dan pendefinisiannya dipengaruhi oleh latar budaya. Konsep penyakit pada masyarakat dapat dibagi menjadi dua kelompok besar berdasarkan penyebabnya; personalistik dan naturalistik. Penyakit personalistik adalah jenis-jenis penyakit yang disebabkan oleh intervensi dari suatu agen aktif yang dapat berupa makhluk supranatural (makhluk gaib atau dewa), makhluk yang bukan manusia (hantu, roh leluhur, atau roh jahat) maupun makhluk manusia (tukang sihir). Penyakit naturalistik adalah penyakit yang disebabkan oleh unsur-unsur dalam tubuh seperti cairan tubuh yang berada dalam keadaan tidak seimbang akibat usia maupun pengaruh lingkungan (Foster dan Anderson, 1986).

Setiap individu memahami penyakit dengan cara beragam pula, dan hal tersebut dipengaruhi oleh berbagai faktor. Kleinman (1980) mengemukakan teori mengenai 'model penjelasan penyakit' (explanatory model of illness) sebagai tanggapan individu memahami penyakit dalam bentuk praktek dan pengalaman.

\section{Perilaku Mencari Pengobatan}

Perilaku mencari pengobatan didefinisikan sebagai perilaku individu atau kelompok dalam memanfaatkan layanan kesehatan untuk mencari kesembuhan; dan perilaku tersebut seringkali menggambarkan tingkat pengetahuan dan kepercayaan individu atau kelompok terhadap layanan kesehatan yang mereka pilih (Cotesea, et al., 2017; Hermawan, et al., 2017). Perilaku pencarian pengobatan dibagi menjadi: 1) mencari pengobatan modern, 2) mencari pengobatan tradisional, 3) tidak mencari pengobatan, 4) dan mengobati sendiri (Notoatmodjo, 2010 dalam Patrika dan Endang, 2012). 
Perilaku mencari pengobatan dipengaruhi oleh berbagai faktor yang kompleks dan holistik yang menunjukkan hubungan antara individu dengan lingkungan sekitarnya. Faktor-faktor tersebut di antaranya: pengetahuan, peran keluarga, petugas kesehatan, kepercayaan, dorongan spiritual, keyakinan, dan kondisi keuangan (Cotesea et al., 2017; Hermawan et al., 2017; Patrika dan Endang, 2012; Sarafino, 2011).

\section{Pemahaman mengenai Penyakit}

Pemahaman berasal dari kata paham yang mempunyai arti suatu proses untuk mengerti benar, cara memahami, cara mempelajari baik-baik supaya paham dan mengetahui banyak (Fajri dan Senja, 2008). Pemahaman mencakup kemampuan untuk menangkap makna dan arti dari aspekyang dipelajari (Winkel, 1996). Pemahaman dipengaruhi oleh faktor internal dan eksternal. Faktor internal meliputi minat, sikap, motivasi individu, sedangkan faktor eksternal meliputi lingkungan, latar belakang sosial ekonomi, dan kebiasaan (Nurhadi, 1987); adapun pemahaman terhadap penyakit adalah suatu proses untuk menangkap makna dari suatu penyakit yang dipengaruhi oleh berbagai faktor; minat, sikap, motivasi, dan lingkungan individu.

\section{Metode}

Penelitian ini dilakukan dengan menggunakan metode etnografi. Etnografi adalah salah satu strategi penelitian kualitatif yang ditujukan untuk mendeskripsikan suatu kelompok kebudayaan dengan cara mengamati, mencatat, dan menuliskannya dalam bentuk deskripsi etnografis (Spradley, 1997). Pengumpulan data dalam penelitian ini dilakukan melalui pengamatan dan wawancara mendalam. Pe ngamatan dilakukan terhadap praktik pencegahan dan penanggulangan yang dilakukan oleh masyarakat pengidap tekanan darah tinggi terkait pemilihan makanan atau obat serta proses pengolahannya. Wawancara etnogra fis dilakukan kepada pengidap tekanan darah tinggi, petugas kesehatan dan keluarga yang merawat mereka. Wawancara dilakukan untuk mencari informasi mengenai gambaran pemahaman, praktik pencegahan, dan penanggulangan tekanan darah tinggi.

\section{Hasil dan Pembahasan}

Desa Cilayung adalah salah satu dari 12 desa di Kecamatan Jatinangor, Kabupaten Sumedang, Provinsi Jawa Barat. Desa ini memiliki luas wilayah 348 ha. Jarak desa dengan pusat kecamatan sekitar empat kilometer, jarak ke kota pemerintahan kabupaten sekitar $27 \mathrm{~km}$, dan jarak ke ibukota provinsi sekitar $32 \mathrm{~km}$.

Desa Cilayung memiliki jumlah penduduk terkecil dibandingkan dengan desa lain di Kecamatan Jatinangor. Jumlah total penduduk Desa Cilayung adalah 5.519 jiwa, terdiri atas 2.283 laki-laki dan 2.696 perempuan. Jumlah KK adalah 1.725 dan tersebar di 11 RW. Kepadatan penduduk Desa Cilayung adalah 1.426 orang per kilometer persegi.

Mata pencaharian penduduk Desa Cilayung sebagian besar sebagai buruh. Tipe pekerjaan ini dibagi menjadi tiga macam yaitu buruh tani (petani penggarap), buruh industri (di pabrik tekstil sekitar desa) dan buruh serabutan di pekerjaan bangunan. Hanya sebagian kecil warga berprofesi sebagai petani pemilik; dengan lahan yang kecil. Budidaya pertanian yang dihasilkan oleh petani adalah padi, jagung, ubi kayu, ubi jalar, kedelai, kacang tanah, dan kacang hijau. Hasil pertanian dijual pada para pengepul perorangan yang selanjutnya akan dibawa ke pasar. Di dalam upaya menjalankan kegiatan perekonomian pertanian, warga biasanya menggunakan fasilitas kredit. Dua fasilitas kredit yang tersedia, antara lain Kredit Usaha Rakyat dan Kredit Usaha Kecil (KUK).

\section{Konsep Lokal mengenai Sakit, Sehat, dan Penyakit}

Pemahaman tentang sakit berbeda-beda antar warga masyarakat. Perbedaan pemahaman tersebut dipengaruhi oleh pengetahuan dan latar belakang kebudayaan masyarakat (Khumaidi, 1989). Pemahaman pada konsep sehat dan sakit sangat dipengaruhi oleh kepercayaan dan tradisi 
lokal (Foster dan Anderson, 1986). Pemahaman tentang sakit kemudian meme-ngaruhi pencegahan dan penanggulangan mereka pada penyakit dan perilaku mencari pengobatan masyarakat (Saraswati, 2009).

Pemahaman masyarakat Desa Cilayung mengenai konsep sakit dan sehat berkaitan dengan kemampuan atau ketidakmampuan individu dalam menjalankan rutinitas. Rutinitas yang dimaksud meliputi bekerja, memasak, mencuci, mengurus anak, dan kegiatan lainnya. Individu yang tidak mampu melakukan rutinitas disebut sakit; sebaliknya, jika mereka mampu melakukan rutinitas tersebut, maka mereka dikatakan sehat.

"Sakit itu ya badan ngerasain gak enak. Kadang kita kalau lakuin kerja juga gak enak. Kalau cuman batuk pilek masih bisa dibawa kerja. Sehat itu biasanya dibawa pas pikiran baik aja neng, pikiran santai gitu." (Wawancara dengan ibu Jamilah 24 Januari 2018)

Konsep sakit menurut pemahaman masyarakat Cilayung pada umumnya merujuk pada kondisi ketidakmampuan seseorang dalam melakukan aktivitas. Masyarakat Cilayung mengatakan bahwa kondisi sakit dikatakan berbahaya apabila berisiko kematian. Beberapa kondisi sakit yang dianggap serius misalnya ketika individu tidak mampu melakukan aktivitas dan hanya dapat terbaring. Kondisi tersebut biasanya akan mengakibatkan kematian.

Kondisi sehat dalam pemahaman masyarakat Cilayung merujuk pada kondisi ketika individu tidak merasakan adanya keluhan yang membuat tubuhnya tidak nyaman. Selain itu, sehat juga diartikan sebagai suatu kondisi kesejahteraan atau 'merasa' baik; dan kondisi saat individu mampu melakukan rutinitas mereka dalam sehari-hari. Artinya, kesehatan bukan hanya tentang penyakit melainkan juga keadaan mental, emosional, dan fisik. Hal itulah yang menyebabkan adanya keberagaman gagasan mengenai konsep sehat dan sakit dalam masyarakat.

Konsep sehat dan sakit yang berkembang di masyarakat Cilayung seringkali menyebab- kan individu merasa sehat walaupun secara medis dinyatakan sakit. Misal, seorang individu memiliki tekanan darah yang sangat tinggi, akan tetapi jika ia masih dapat beraktivitas sehari-hari, maka ia dan warga masyarakat menyebut orang tersebut sehat.

Pemahaman konsep sehat oleh masyarakat berbeda dengan pemahaman petugas kesehatan. Bidan Sri dan Bidan Elis, bidan desa setempat, menyatakan bahwa banyak warga merasa nyaman sekalipun memiliki penyakit. Hal ini menyebabkan mereka lambat melakukan deteksi dini penyakit. Warga Desa Cilayung biasanya mengunjungi Puskesmas dan atau mendatangi Posyandu untuk meminta obat ke petugas kesehatan ketika benar-benar merasa sakit.

Warga Desa Cilayung memiliki pengetahuan luas mengenai aneka jenis penyakit dan penyebabnya. Penyakit yang umum mereka ketahui adalah TBC, reumatik, maag, tekanan darah tinggi, dan kolesterol. Penyakit-penyakit itu adalah penyakit yang umum diderita masyarakat setempat.

\section{Pemahaman mengenai Tekanan Darah Tinggi}

Pemahaman masyarakat Desa Cilayung mengenai tekanan darah tinggi dapat dilihat dari cara mereka menjelaskan mengenai tekanan darah tinggi dan gejala yang menyebabkan tekanan darah tinggi. Tekanan darah tinggi di kalangan masyarakat Desa Cilayung biasanya disebut dengan istilah tensi.

Masyarakat Cilayung juga mengetahui bahwa tekanan darah tinggi adalah penyakit yang bisa menyebabkan stroke. Stroke ini yang biasanya ditakuti oleh masyarakat karena beresiko terhadap kematian secara tiba-tiba. Selain itu, tekanan darah tinggi di Desa Cilayung menurut masyarakat biasanya terjadi di kalangan lansia dan kalangan ibu hamil. Kasus tekanan darah tinggi pada ibu hamil dianggap disebabkan oleh bawaan bayi. Setelah proses melahirkan, tekanan darah akan kembali normal. Tekanan darah tinggi pada kalangan lansia, dianggap disebabkan oleh banyak faktor baik genetik 
maupun non-genetik.

Penyebab darah tinggi menurut warga Cilayung, yaitu:

\section{Terlalu banyak pikiran}

Masyarakat seringkali menyebut bahwa pikiran sangat berpengaruh pada kesehatan seseorang. Faktor ekonomi sering disebut masyarakat sebagai salah satu faktor yang memengaruhi kondisi pikiran seseorang. Hal ini kemudian memengaruhi kondisi kesehatan. Kondisi ekonomi yang kurang baik menjadi beban pikiran yang kemudian memicu datangnya sakit. Para perempuan merasa bahwa tekanan ekonomi membuat mereka mengalamai tekanan daran tinggi.

"Ya kan perempuan sering ga punya uang, jadi tensi naik. Suami teh kalau kerja kadang tidak bawa uang yang cukup untuk kebutuhan. Harus kerja istrinya juga, jadi repot neng." (Wawancara dengan Bu Dede 25 Januari 2018).

\section{Terlalu banyak aktivitas dan kelelahan}

Masyarakat Cilayung mempercayai bahwa kelelahan karena terlalu banyak aktivitas dapat menyebabkan penyakit. Fisik yang dipaksa untuk bekerja, mengakibatkan tubuh lelah dan sakit. Jamilah misalnya, sering mengalami sakit lutut dan ia yakin penyakit itu akibat ia terlalu lelah bekerja. Nenah juga mengaitkan kondisi tekanan darahnya dengan kelelahan.

\section{Makanan}

Masyarakat mengetahui bahwa makanan dengan kandungan garam tinggi dapat menyebabkan penyakit darah tinggi, tetapi mereka mengakui kesulitan mengurangi konsumsi garam. Bahkan para kader kesehatan yang telah memiliki pengetahuan mengenai pencegahan darah tinggi pun tak dapat mengurangi konsumsi mereka akan makanan berasa asin. "Kalau gak asin gak enak" adalah alasan warga saat ditanya mengenai kegemaran mereka mengonsumsi makanan yang diasinkan.

Masyarakat Desa Cilayung gemar makan makanan asin, seperti ikan asin dan ikan pindang. Makanan tersebut, dikonsumsi dengan nasi liwet, sayur lalap, dan sambal. Bahan yang mereka konsumsi biasanya mereka dapatkan dengan cara membeli. Selain orang tua yang gemar makanan asin, anak-anak juga terbiasa makan makanan asin. Mereka beranggapan bahwa makanan yang tidak asin adalah makanan yang tidak enak.

Ikan asin menjadi salah satu makanan yang penting bagi masyarakat. Pasalnya ikan asin adalah makanan yang bisa bertahan lama, sehingga tidak akan basi ketika disimpan. Sehingga dengan menggunakan ikan asin sebagai lauk akan menghemat pengeluaran untuk makanan selain rasa asin yang digemari.

Selain menambahkan rasa asin dalam makanan, masyarakat Desa Cilayung suka menambahkan penyedap rasa dalam makanan untuk menambah rasa gurih terhadap makanan. Penyedap rasa sudah menjadi bumbu wajib dalam memasak, sama seperti garam.

Warga berpendapat bahwa, meski mereka mengonsumsi asin secara sering, jumlahnya tidak banyak sehingga dianggap masih aman. Warga justru lebih mewaspadai makanan lain yang mereka percaya menyebabkan tekanan darah tinggi antara lain kopi, petai, penyedap rasa, telur, singkong, dan daging kambing. Warga mengatasi ancaman darah tinggi setelah mengonsumsi makanan penyebab dengan cara mengkonsumsi makanan penawar, wortel, ketimun, dan labu siam.

\section{Keturunan}

Masyarakat Cilayung meyakini bahwa sakit juga dapat terjadi karena faktor keturunan.

"Biasanya kalau darah tinggi itu ada karena keluarganya ada yang darah tinggi juga Tapi itu juga bisa dari kebiasaan makan Neng." (Wawancara dengan Bu Aisyah 24 Januari 2018).

\section{Pola Aktivitas Fisik dan Kerja}

Gambaran aktivitas fisik dan pola kerja masyarakat Desa Cilayung dapat diamati dari detail keseharian mereka. Pada pagi hari, anak- 
anak berangkat ke sekolah, pemuda dan orang tua masih di rumah; para ibu rumah tangga biasanya membersihkan rumah dan para laki-laki bersiap untuk kerja. Anak-anak bermain di lapangan sekolah setelah pulang dari sekolah. Mereka juga suka jajan makanan ringan di sekitar sekolah pada waktu siang atau sore hari. Jajanan yang mereka beli adalah cilor, batagor, dan martabak mini.

Pada siang hari biasanya para laki-laki sudah pulang dari kebun untuk beristirahat kemudian berdiam diri di dalam rumah. Ketika sore tiba, anak-anak pulang ke rumah. Ibu mempersiapkan masakan di dapur dan membersihkan rumah. Para ibu dan anak muda kadang bermain voli di lapangan. Beberapa dari mereka diam di rumah karena memiliki kesibukan mengasuh anak atau cucu. Masyarakat Desa Cilayung jarang melakukan aktivitas fisik lainnya seperti olahraga.

\section{Praktik Pengobatan Penyakit}

Sejak tersedia Puskesmas di Kecamatan Jatinangor, pola pencarian pengobatan masyarakat berubah. Sebelum ada Puskesmas, masyarakat menggunakan cara pengobatan tradisional. Namun, mereka menyadari bahwa pengobatan dengan cara tradisional kadang kurang maksimal, sementara obat dari Puskesmas memberikan dampak kesembuhan lebih cepat. Walaupun demikian, masih ada beberapa masyarakat menggunakan pengobatan tradisional untuk menyembuhkan penyakit yang mereka derita.

Pola pencarian pengobatan di Desa Cilayung ini biasanya diawali dengan pengobatan sendiri. Mereka biasanya menggunakan obat tradisional yang telah digunakan keluarga secara turun temurun sebagai langkah pertama pengobatan. Ketika obat tradisional itu memberi dampak kesembuhan, mereka tidak lagi mencari pengobatan lainnya. Namun, jika obat tradisional yang mereka gunakan tidak membuat mereka sembuh, mereka kemudian datang ke petugas kesehatan. Petugas kesehatan yang mereka datangi biasanya adalah bidan desa.

Pengidap tekanan darah tinggi di Desa
Cilayung sudah mengetahui gejala yang dirasakan ketika tekanan darah sedang meningkat, seperti sakit kepala dan sakit leher hingga pundak. Ketika mengalami gejala tersebut, pengidap tekanan darah tinggi biasanya langsung datang ke tempat pelayanan kesehatan atau melakukan pengobatan tradisional.

Jamilah, salah seorang pengidap tekanan darah tinggi segera mengonsumsi obat ketika merasakan gejala tekanan darah tinggi. Obat yang biasa dikonsumsi adalah obat dari apotik, bernama Captopril. Jamilah biasanya mendapatkan obat dibantu oleh anak menantunya. Seila, anak Jamilah, mengatakan

"Ya tahu juga kalau darah tinggi bisa dituruni dengan air pepaya. Tapi suka lama sembuhnya, mendingan pake Captopril langsung yang beli di apotek. Biasanya suami saya yang beli untuk mamah."

Kegiatan untuk penyakit tidak menular dan Posbindu Lansia biasanya bersatu dengan kegiatan Posyandu. Di dalam pelaksanaannya, petugas kesehatan sering berhalangan hadir karena melakukan kunjungan ke desa lain di jadwal yang sama. Apabila petugas kesehatan berhalangan hadir, mereka biasanya dibantu dengan kader. Koordinator kader mengunjungi setiap kegiatan Posyandu dan Polindes di setiap RW. Koordinator kader dibantu dengan kader tiap RW melakukan kegiatan Posyandu dan Polindes. Setiap kader yang ada di tiap RW sudah mendapatkan pelatihan untuk observasi dan mencatat rekam medis tekanan darah tinggi tiap masyarakat. Kader yang mendapatkan pelatihan tersebut antara lain dari RW 1, RW 2, RW 5, dan RW 8. Kegiatan Posbindu lansia meliputi penimbangan, pengukuran tekanan darah tinggi, dan pengobatan.

Pelaksanaan pemeriksaan tekanan darah tinggi di Desa Cilayung menghadapi hambatan. Warga kadang-kadang tidak mau diperiksa oleh kader. Komariah, salah satu warga berkata bahwa dirinya jarang memeriksakan diri ke kader.

"Saya jarang periksa kalau ke kader, 
ini kan kader baru dilatih. Nanti saja kalau kader sudah biasa meriksa, saya baru meriksa tekanan darah saya. Sekarang mah nunggu Bu bidan dulu."

Warga Cilayung juga masih menggunakan obat tradisional untuk pengobatan pertama pada keluhan fisik. Mereka lebih memilih obat tradisional atau obat herbal yang berasal dari bahan alami karena mereka beranggapan bahwa obat tradisional lebih aman untuk dikonsumsi.

Beberapa tanaman yang biasa digunakan sebagai bahan obat tradisional untuk darah tinggi antara lain:

1) Daun Karet Kebo (Ficus elastica)

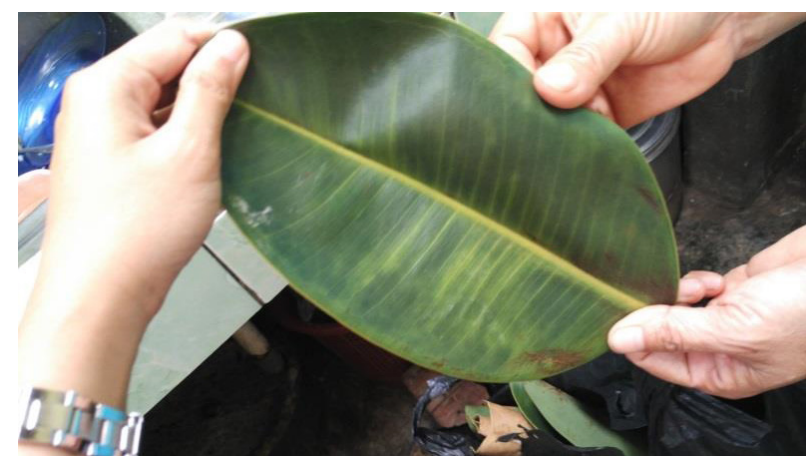

Gambar 1. Daun Karet Kebo (Sumber: Dokumentasi Peneliti)

Daun karet kebo biasanya digunakan untuk pengobatan darah tinggi. Caranya adalah dengan merebus sebanyak 5-10 lembar daun karet kebo hingga warna air menjadi hijau keruh. Air rebusan kemudian didinginkan dan diminum sehari sekali satu gelas.

\section{2) Daun Sirsak (Annona muricata)}

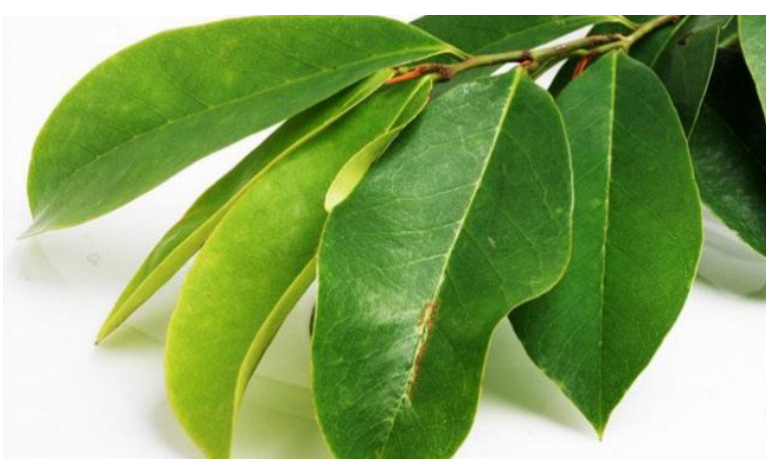

Gambar 2. Daun Sirsak (Sumber: viva.co.id)

Daun sirsak juga digunakan oleh masyarakat
Cilayung untuk menyembuhkan tekanan darah tinggi. Cara mengolahnya yaitu dengan mengambil beberapa lembar daun sirsak kemudian direbus dengan air secukupnya. Setelah mendidih, air rebusan daun sirsak kemudian didinginkan. Air rebusan yang telah dingin kemudian diminum satu kali sehari. Daun sirsak cukup familiar digunakan masyarakat sebagai obat karena daun sirsak tidak sulit didapatkan.

\section{3) Kulit Manggis (Garcinia mangostana)}

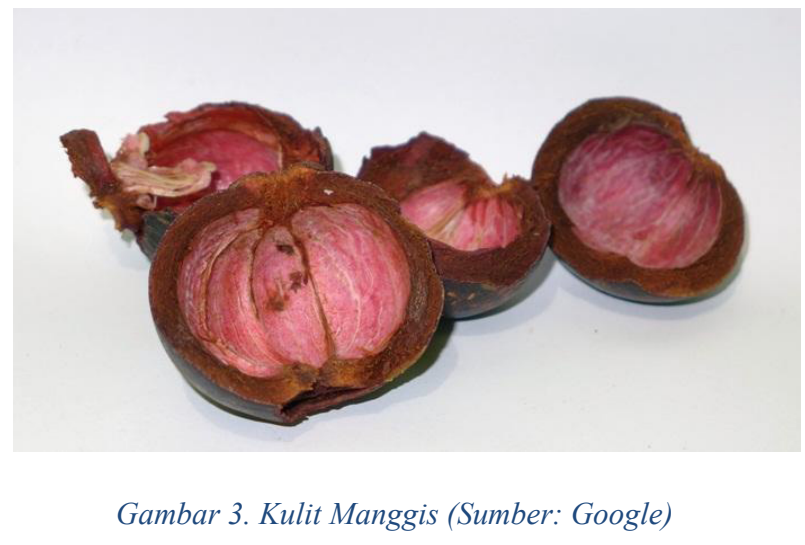

Kulit manggis menjadi salah satu obat tradisional yang dianggap ampuh menyembuhkan tekanan darah tinggi oleh masyarakat Desa Cilayung. Kulit manggis diambil sarinya dengan cara direbus. Air rebusan akan berwarna ungu kehitaman. Air rebusan yang telah didinginkan, kemudian diminum teratur satu kali sehari. Kulit manggis biasanya didapatkan masyarakat dengan membeli buah manggis di pasar. Setelah buahnya dimakan, kemudian kulit manggis disisihkan untuk dibersihkan dan dijadikan obat tradisional.

\section{4) Mentimun/ Bonteng(Cucumis sativus)}

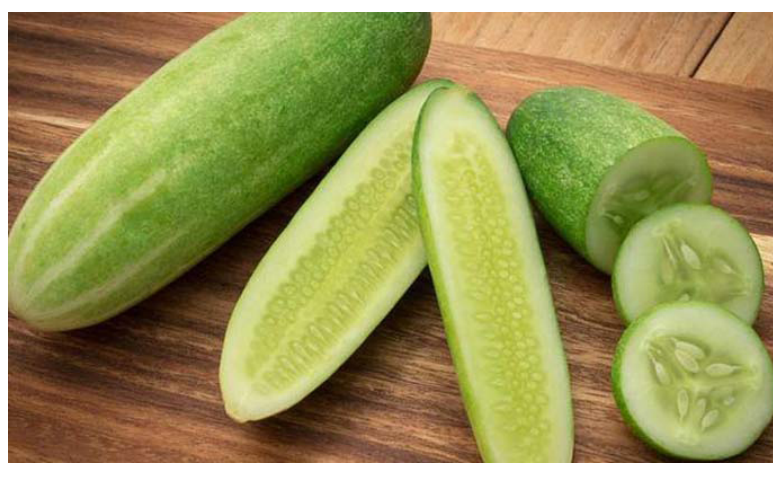

Gambar 4. Mentimun (Sumber: Google)

Mentimun dianggap ampuh untuk menurunkan tekanan darah tinggi. Mentimun mudah digu- 
nakan sebagai obat. Mentimun cukup dibersihkan dengan air bersih kemudian langsung dimakan. Mentimun cukup mudah. didapatkan di pasar ataupun di warung yang dekat dari rumah.

\section{5) Labu Siam/ Waluh (Cucurbita moschata)}

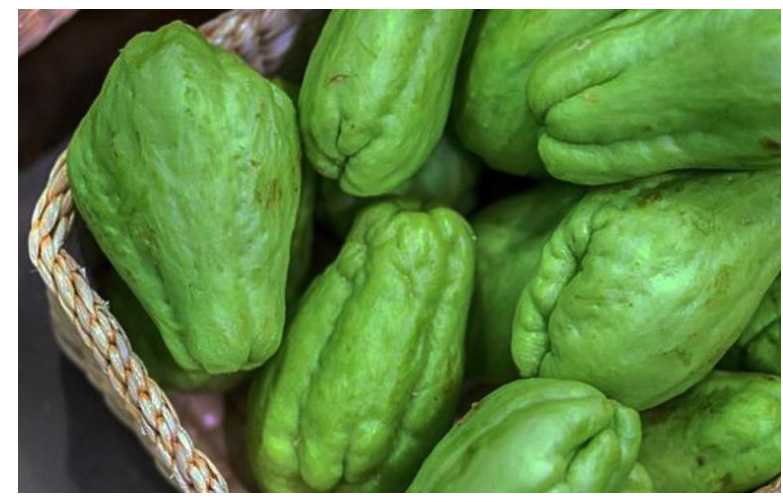

Gambar 5. Labu Siam/Waluh (Sumber: Google)

Waluh dipercaya masyarakat sebagai obat yang dapat menurunkan tekanan darah tinggi. Cara mengolahnya yaitu dengan merebus waluh dengan air secukupnya. Air rebusan tersebut kemudian didinginkan dan diminum rutin satu hinga tiga kali sehari (bergantung pada kebutuhan). Waluh dapat diperoleh masyarakat dengan cara membeli di pasar sayur atau di kebun.

\section{6) Belimbing (Averrhoa carambola L)}

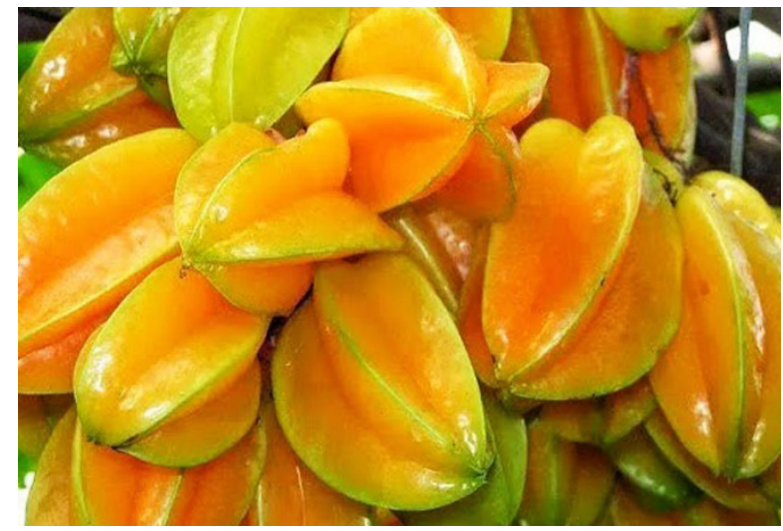

Gambar 6. Belimbing (Sumber: Google)

Belimbing juga dianggap mampu menurunkan tekanan darah tinggi. Cara mengolahnya yaitu dengan merebus belimbing dengan perbandingan satu buah belimbing dengan satu gelas air putih. Air rebusan yang sudah dingin diminum rutin satu hari sekali.

\section{7) Daun Alpukat (Persea americana)}

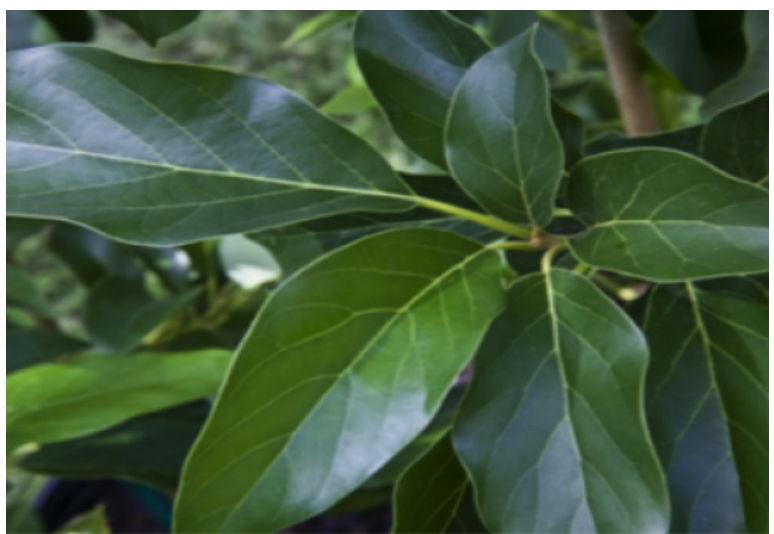

Gambar 7. Daun Alpukat (Sumber: Google)

Daun alpukat dikenal masyarakat sebagai salah satu obat tradisional yang dapat menurunkan tekanan darah tinggi. Cara mengolahnya yaitu dengan mengambil tiga lembar daun alpukat dan ditambahkan satugelas air putih kemudian direbus. Air rebusan daun alpukat ini akan berwarna hijau kecoklatan. Air rebusan ini kemudian didinginkan dan diminum satu hingga tiga kali sehari. Daun alpukat biasanya didapat masyarakat dari kebun. Pasalnya terdapat beberapa masyarakat yang menanam buah alpukat ini di kebun sehingga akses untuk mendapatkan daun alpukat ini tidaklah sulit.

\section{Simpulan}

Penyakit tekanan darah tinggi dipahami oleh masyarakat Desa Cilayung sebagai penyakit yang disebabkan oleh terlalu banyak pikiran, terlalu banyak aktivitas, terlalu banyak konsumsi garam, dan keturunan. Di dalam bahasa setempat, tekanan darah tinggi disebut sebagai tensi. Masyarakat Cilayung mengenali gejala-gejala penyakit darah tinggi di antaranya sakit kepala dan leher hingga pundak. Apabila gejala tersebut sudah muncul, praktik yang biasa dilakukan oleh masyarakat dalam upaya menanggulangi penyakit tersebut adalah dengan mengurangi konsumsi garam dan mengonsumsi obat-obatan herbal maupun obat yang diperoleh dari Puskesmas. Obat herbal yang mereka gunakan untuk pengobatan darah tinggi antara lain daun karet kebo, daun sirsak, kulit manggis, mentimun, labu siam, belimbing, dan daun alpukat. Faktor yang 
mempengaruhi pemahaman dan praktik masyarakat Desa Cilayung dalam pencegahan dan penanggulangan tekanan darah tinggi adalah konsep lokal mengenai penyakit dan cara-cara penanggulangannya.

\section{Daftar Pustaka}

Cotesea, J. P., Nyorong, M., dan Ibnu, I. F. (2017). Perilaku Pencarian Pengobtan Masyarakat terhadap Penyakit Malaria di Kelurahan Remu Utara, Distrik Sorong, Kota Sorong Papua Barat. Repos Univ Hasanudin, 2(1), 155-162.

Den Hartog, A. P., Van Staveren, W. A., dan Brower, I. D. (1995). Manual for Social Surveys on Food Habits and Consumption in Developing Countries. Germany: Margraf Verlag.

Departemen Kesehatan Republik Indonesia. (2006). Pedoman Perawatan Kesehatan Usia Lanjut di Rumah. Jakarta: Departemen Kesehatan Republik Indonesia.

Foster, G. M., dan Anderson, B. G. (1986). Medical Anthropology. New York: University of California Press.

Galton, L. (1973). The Silent Disease: Hypertension. New York: Crown.

Hanif, M., dan Asri, D. N. (2016). Perilaku dan Interaksi Sosial Masyarakat Kampung Idiot Desa Sidoharjo dan Desa Krebet Kecamatan Jambon Kabupaten Ponorogo. Studi Counsellia: Jurnal Bimbingan Dan Konseling, 3(2), 1-29.

Harper, L. J., Deaton, B. J., dan Driskel, J. A. (1985). Pangan, Gizi, dan Pertanian. Jakarta: UI Press.

Hartati, S., dan Fani, T. (2017). Sistem Pendukung Keputusan Mendiagnosa Gejala Penyakit Darah Tinggi menggunakan Metode Fuzzy Multiple Attribute Decision Making (FMADM). Jurnal TAM (Technology Acceptance Model), 6, 29-36.

Hermawan, C., Anggraeni, R., dan Setianingsih, S. (2017). Gambaran Upaya dalam Mencari Bantuan Kesehatan pada Masyarakat. Jurnal Keperawatam, 9(2), 52-59.

Khumaidi, M. (1989). Gizi Masyarakat. Bogor: Departemen Pendidikan dan Kebudayaan dan Direktorat Jenderal Pendidikan Tinggi dan Pusat Antar Universitas Pangan dan Gizi IPB.

Kleinman, A. (1980). Patients and Healers in Ther Context of Culture. Berkeley: University of
California Press.

Muhammadun. (2010). Hidup Bersama Hipertensi. Yogyakarta: In Books.

Mulyantoro, D., Dhermawan, H. S., dan Permatasari, E. (2016). Hipertensi Pembunuh Senyap Etnik Melayu di Kampung Bilis. Yogyakarta: Kanisius.

Notoatmodjo. (2010). Pendidikan dan Perilaku Kesehatan. Jakarta: Rineka Cipta.

Nurfita, D. (2012). Budidaya, Khasiat, dan Cara Olah Mengkudu. Yogyakarta: Pustaka Baru Press.

Palemer, A., dan Williams, B. (2007). Tekanan Darah Tinggi. Jakarta: Erlangga.

Patrika, F. J., dan Endang, S. (2012). Hubungan antara Efikasi dengan Perilaku Mencari Pengobatan pada Penderita Kanker Payudara di RSUD Ibnu Sina Gresik. Jurnal Psikologi Klinis Dan Kesehatan Mental, 1(2), 138144.

Prayugi, S. D., Mursaha, A., dan Lewa, A. F. (2017). Faktor Sosial Budaya yang Berhubungan dengan Pola Konsumsi Makanan pada Masyarakat Suku Kaili di Kota Palu Propinsi Sulawesi Tengah. Poltekita: Jurnal Ilmu Kesehatan, 1(8).

Sarafino. (2011). Health Psychology: Biopsychosocial Interactions (5th ed.). USA: John Wiley Sons.

Saraswati, S. (2009). Diet bagi Penderita Penyakit Hipertensi. Yogyakarta: A-plus Books.

Suhardjo. (1989). Sosio Budaya Gizi. Bogor: Departemen Pendidikan dan Kebudayaan Direktorat Jenderal Pendidikan Tinggi dan Pusat Antar Universitas Pangan dan Gizi IPB.

Wahyuni, S. (1988). Konsumsi Ikan, Kebiasaan Makan Anak Balita, dan Status Gizi Anak Sekolah Keluarga Nelayan dan Bukan Nelayan di Kelurahan Tambak, Kecamatan Kenjeran, Kotamadya Surabaya, Jawa Timur. Institut Pertanian Bogor.

Wardiatmo, T. (1989). Makanan dalam Arti Sehat dan Sosial. Buletin Gizi, 2(13).

Widyasari, R. (2014). Si Pembunuh Senyap, Tinggi Dara. Jakarta: Balitbangkes.

William, L. (2008). Understanding Medical Surgical Nursing, Third Edition. America: F.A Davis Company. 